\title{
Synthesis of Glycosylated Haemoglobin in Vivo
}

\author{
P. Aa. Svendsen, J. Sandahl Christiansen, U. Søegaard and J. Nerup \\ Steno Memorial Hospital, Gentofte, Denmark
}

Summary. The synthesis of glycosylated haemoglobins in vivo was measured during $24 \mathrm{~h}$ of controlled hyperglycaemia in seven insulin dependent diabetics. The mean blood glucose concentration was $22 \mathrm{mmol} / \mathrm{l}$, while electrolytes and other metabolites were kept normal by infusion of 4-23 IU of insulin during hyperglycaemia. The study confirmed the velocity and magnitude of unstable $\mathrm{HbA}_{1 \mathrm{c}}$ formation previously found in vitro. The stable $\mathrm{HbA}_{\mathrm{Ic}}$ formed in $24 \mathrm{~h}$ was on average $0.006 \%$ of total haemoglobin/ mmol glucose. This compares well with the rate of $\mathrm{HbA}_{1 \mathrm{c}}$ synthesis reported in normal subjects using ${ }^{59} \mathrm{Fe}$-kinetic measurements, and is in accordance with the concept of slow changes in stable $\mathrm{HbA}_{1 \mathrm{c}}$ with time and glucose concentration. To investigate the possibility that the rate of $\mathrm{HbA}_{1 \mathrm{c}}$ synthesis varies with erythrocyte age, glycosylated haemoglobins were measured in erythrocyte fractions after density separation on Percoll-Albumin gradients. We found both in normal subjects and in insulin treated diabetics that the $5 \%$ least dense cells contained $70 \%-80 \%$ of whole blood $\mathrm{HbA}_{1 \mathrm{c}}$. Assuming the least dense cells to be the youngest erythrocytes, this observation is inconsistent with a slow linear increase in $\mathrm{HbA}_{\mathrm{Ic}}$. Similar results were obtained in six newly diagnosed insulin dependent diabetic patients both before and after the first 30 days of insulin treatment, even though a marked decrease in young cell $\mathrm{HbA}_{1 \mathrm{c}}$ would be expected with the improved glucose control observed. We therefore conclude that density separation of erythrocytes is an inadequate technique to study age related $\mathrm{HbA}_{1 c}$ synthesis.

Key words: Haemoglobin $A_{1 c}$, synthesis, glucose, hyperglycaemia, artificial pancreas, density separated erythrocytes.
In subjects with constant blood glucose levels, clinical studies have confirmed that the concentration of haemoglobin $\mathrm{A}_{1 \mathrm{c}}\left(\mathrm{HbA}_{1 \mathrm{c}}\right)$ is proportional to fasting or mean blood glucose concentrations [1, 2]. Recent reports of rapid changes in the aldimine precursor of stable $\mathrm{HbA}_{1 \mathrm{c}}$ and of its co-determination in chromatographic methods [3-5] may eventually help to clarify the connection between mean blood glucose and stable $\mathrm{HbA}_{1 \mathrm{c}}$ in subjects with unstable glucose levels, i. e. in insulin-treated insulin-dependent diabetic patients. The rational use of $\mathrm{HbA}_{\mathrm{Ic}}$ in clinical assessment of long-term glycaemic control needs to be based on knowledge of rates of synthesis and dissociation of glycosylated haemoglobins. Hitherto few reports have considered this problem.

Using ${ }^{59}$-Fe-labelled $\mathrm{HbA}$, Bunn et al. [6] found $24 \mathrm{~h}$ synthesis to be in the order of $0.01 \% \mathrm{HbA}_{\mathrm{lc}} /$ mmol glucose in vivo in two normal subjects. Using a first order kinetic model, Beach [7] calculated the observed rate to be consistent with data for total glycosylated haemoglobins $\left(\mathrm{HbA}_{1}\right)$ and glucose concentrations reported in the literature. From the model, Beach also concluded that about one-quarter of average erythrocyte $\mathrm{HbA}_{1 \mathrm{c}}$ might be present when new erythrocytes are released into the circulation. In contrast, Labie et al. [8] reported absence of $\mathrm{HbA}_{\mathrm{lc}}$ in erythroblasts, but like Fitzgibbons et al. [9] he found a relatively large proportion of average erythrocyte $\mathrm{HbA}_{\mathrm{lc}}$ to be present in the $10 \%$ least dense eryhtrocytes, supposed to be the $10 \%$ youngest cells, separated by density gradient centrifugation. Recently, in a group of insulin independent diabetic patients, Boden et al. [10] reported an increase in total $\mathrm{HbA}_{1}$ of $1.5 \%$ in 7 days following a mean increase in fasting plasma glucose of $2.2 \mathrm{mmol} / 1$. This represents a $24 \mathrm{~h}$ synthesis close to $0.1 \% \mathrm{HbA}_{1} / \mathrm{mmol}$ glucose increment.

Such differences in synthesis of glycosylated haemoglobins in vivo clearly create doubts about the 
clinical interpretation of $\mathrm{HbA}_{\mathrm{lc}}$ results as indicators of long-term glycaemic control in diabetics.

Therefore our study was undertaken: (1) to determine $\mathrm{HbA}_{\mathrm{lc}}$ synthesis during a $24 \mathrm{~h}$ period of controlled hyperglycaemia, and (2) to measure glycosylated haemoglobins in density separated erythrocytes, evaluating this technique as a means of studying time relations in haemoglobin glycosylation.

\section{Materials and Methods}

\section{Glycosylated Haemoglobins}

Chromatographic determination of glycosylated haemoglobin fractions $\left(\mathrm{HbA}_{1 a+b}\right.$ and $\left.\mathrm{HbA}_{\mathrm{c}}\right)$ was performed as previously described [5]. The range determined in normal controls was $4.1 \%-6.4 \%$ of total haemoglobin (mean $\pm 2 \mathrm{SD}$ ). Total $\mathrm{HbA}_{\mathrm{lc}}$ and $\mathrm{Hb} A_{\mathrm{la}+\mathrm{b}}\left(t \mathrm{~A}_{\mathrm{ic}}\right.$ and $\left.\mathrm{t} \mathrm{A}_{\mathrm{Ia}+\mathrm{b}}\right)$ were determined after a maximum of $24 \mathrm{~h}$ storage of heparinized whole blood samples at $4{ }^{\circ} \mathrm{C}$. Stable $\mathrm{HbA}_{\mathrm{la}+\mathrm{b}}$ and $\mathrm{HbA}_{\mathrm{lc}}$ (incubated fractions $=\mathrm{iA}_{\mathrm{la}+\mathrm{b}}, \mathrm{iA}_{\mathrm{lc}}$ ) were measured after a $6 \mathrm{~h}$ incubation at $37^{\circ} \mathrm{C}$ of blood samples diluted in $0.15 \mathrm{~mol} / 1$ saline [5].

The thiobarbiturate method as modified by Pecoraro et al. [11] was used to determine ketoamine-bound glucose in haemolysates. Saline-washed erythrocytes were used for preparation of haemolysates with a haemoglobin concentration of $0.625 \mathrm{mmol} / 1$. For control of the thiobarbiturate method, a $100 \mu \mathrm{mol} / 1$ fructose solution was determined in each assay, and mean absorbance at $443 \mathrm{~nm}$ was 0.170 with a day-to-day coefficient of variation of $2 \%$.

Blood glucose concentration was determined by a modification of the Trinder glucose oxidase method [12]. Plasma sodium, potassium and bicarbonate $\left(\mathrm{pCO}_{2}=40 \mathrm{mmHg}\right)$ were determined by standard clinical chemistry procedures, plasma non-esterified fatty acids (NEFA) by colorimetry [13] and 3-hydroxybutyrate enzymatically [14].

\section{$H b A_{l c}$ Synthesis In Vivo}

Seven insulin-dependent diabetic in-patients (one female, six males) were carefully instructed about the nature of the investigation before giving their consent to participate. Their mean age was 32 years (range $20-44$ years), and the duration of diabetes $1-23$ years. During SC insulin therapy they received a daily dose of insulin of $0.40 \mathrm{UI} / \mathrm{kg}$ (range $0.14-0.65 \mathrm{IU} / \mathrm{kg}$ ). Body weight was within $82 \%-118 \%$ (mean $99 \%$ ) of ideal body weight. The mean of five blood glucose determinations during the $24 \mathrm{~h}$ before connection to the artificial betacell ranged from 4.0 to $12.5 \mathrm{mmol} / 1$ (mean $8.4 \mathrm{mmol} / \mathrm{l}$ ).

After connection to the artificial betacell (Biostator), normoglycaemia of 5-6 mmol/ 1 was maintained for at least $6 \mathrm{~h}$ before induction of hyperglycaemia by oral ingestion of $100 \mathrm{~g}$ of $\mathrm{D}$-glucose, supplemented by IV infusion of glucose by the Biostator to maintain a blood glucose concentration of approximately $22 \mathrm{mmol} / \mathrm{l}$. An extra $25 \mathrm{~g}$ of glucose were given orally whenever blood glucose fell below $18 \mathrm{mmol} / 1$. At a blood glucose concentration of $22 \mathrm{mmol} / \mathrm{l}$, the patients received an infusion of insulin $0.01 \mathrm{IU} / \mathrm{min}$. Supplementary insulin was infused when blood glucose exceeded $22 \mathrm{mmol} / 1$ or if plasma ketone bodies increased (Ketostix).

Hyperglycaemia was terminated after $24 \mathrm{~h}$ by reprogramming the Biostator to maintain a blood glucose concentration of $4.5 \mathrm{mmol} / 1$, and normoglycaemia was reached in all patients with- in 2-3 h. Normoglycaemia was maintained for a further $6 \mathrm{~h}$ before the end of the experiment.

During the experiment the patients had their usual diets and performed ergometer cycling for exercise if desired. Starting $2 \mathrm{~h}$ before induction of hyperglycaemia, blood was sampled every $2 \mathrm{~h}$ for determination of glycosylated haemoglobins, electrolytes, non-esterified fatty acids (NEFA) and 3-hydroxybutyrate. During hyperglycaemia all samples were screened for ketone bodies using $\mathrm{Ke}-$ tostix. Total $\mathrm{HbA}_{1 \mathrm{c}}$ was determined in all samples, and $\mathrm{iA}_{\mathrm{lc}}$ by quadruplicate determinations in samples collected $0,16,24$ and $32 \mathrm{~h}$ after induction of hyperglycaemia.

\section{Density Separation of Erythrocytes}

Density separation of erythrocytes was carried out on Percoll-albumin gradients as described and evaluated by Rennie et al. [15], starting the separation procedure within $2 \mathrm{~h}$ of blood collection. For each sample exploratory gradients, usually containing 57\%-65\% Percoll, were run to find the density mixture leaving fewer than $10 \%$ of the cells in the upper layer. This mixture was used for preparation from $0.5 \mathrm{ml}$ whole blood aliquots of sufficient 'low density cells' for counting and determination of glycosylated haemoglobin fractions.

The numbers of erythrocytes applied to the density mixture and recovered from the upper layer after centrifugation were counted, and the reticulocyte fraction was determined both in whole blood and in the 'low density cells'. Both whole blood and low density cells were incubated in glucose $2 \mathrm{mmol} / 1$ in saline $0.15 \mathrm{~mol} / 1$ for $6 \mathrm{~h}$ at $37^{\circ} \mathrm{C}$ before preparation of haemolysates for determination of stable glycosylated haemoglobins. All chromatographic determinations were performed in duplicate. Blood for density separation of erythrocytes was obtained from: (1) eight consecutive insulin dependent diabetic out-patients; (2) six non-diabetic volunteers from the hospital staff; and (3) six consecutive newly diagnosed diabetics both before and 31-35 days after the start of insulin treatment.

The newly diagnosed diabetics were all admitted to the hospital with mild to moderate ketonuria, but without acidosis (standard bicarbonate 19-24 mmol/1). All six were males aged 14-26 years and having a body weight of $82 \%-96 \%$ of ideal body weight. At admission they had blood glucose values from 16 to $24 \mathrm{mmol} / 1$ and excreted 53-115 g glucose in the urine during the first $24 \mathrm{~h}$. They stayed as in-patients for 10-14 days and on discharge were treated with $1840 \mathrm{IU}$ insulin/day. During the last three days in hospital, the mean blood glucose values ranged from 7.0 to $12.8 \mathrm{mmol} / 1$ (mean $9.1 \mathrm{mmol} / 1$ ). At the first visit to the out-patient clinic, $31-35$ days after start of the insulin treatment, their fasting blood glucose values ranged from 5.0 to $13.8 \mathrm{mmol} / 1$ (mean $7.7 \mathrm{mmol} / 1$ ).

Results are given as mean values \pm SEM. Student's ' $t$ ' test and Wilcoxons rank sum test were used for statistical calculations.

\section{Results}

To maintain a hyperglycaemia of $22 \mathrm{mmol} / \mathrm{l}$ the patients received on average $503 \mathrm{~g}$ of glucose (range $312-1145 \mathrm{~g}$ ) and excreted $319 \mathrm{~g}$ (approximately 63\%) in the urine. A mean dose of $15 \mathrm{IU}$ insulin (range 4-23 IU) was infused during the hyperglycaemic period.

The results for increases in total $\mathrm{HbA}_{1 \mathrm{c}}\left(\mathrm{tA}_{1 c}\right)$, stable $\mathrm{HbA}_{1 \mathrm{c}}\left(\mathrm{iA}_{1 \mathrm{c}}\right)$ and blood glucose concentrations are shown in Figure 1. Before induction of hyperglycaemia, stable $\mathrm{HbA}_{1 \mathrm{c}}$ ranged from $5.5 \%$ to $10.5 \%$ of to- 


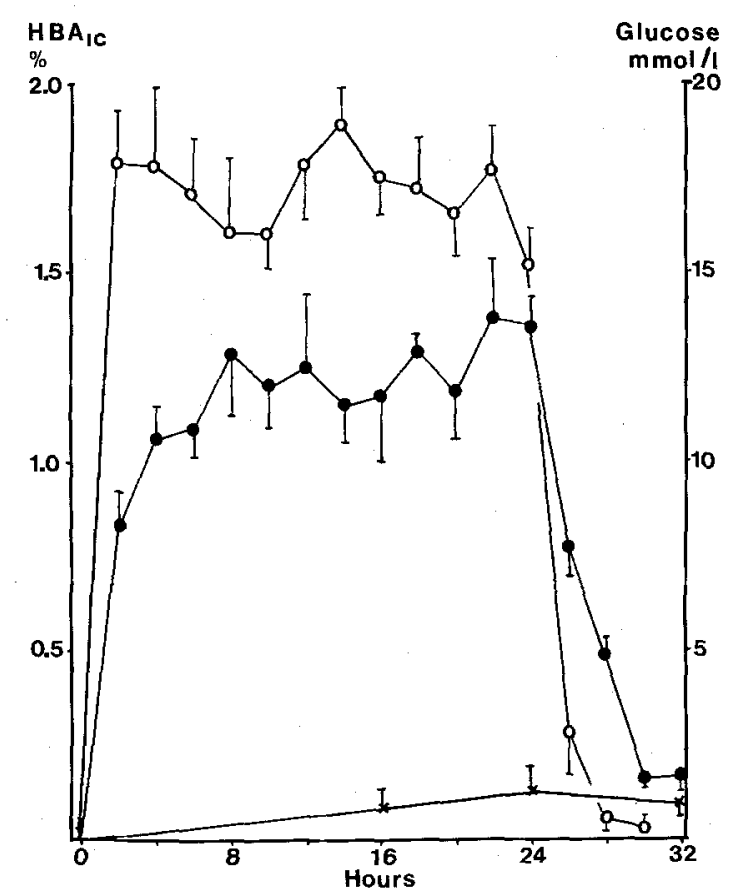

Fig. 1. Changes in glucose concentration $\left(\mathrm{O}_{-}-\mathrm{O}_{-}\right)$, total $\mathrm{HbA}_{1 \mathrm{c}}$ (-_ and stable $\mathrm{HbA}_{\mathrm{Ic}}$ determined after incubation of erythrocytes in $\mathrm{NaCl} 0.15 \mathrm{~mol} / \mathrm{l}(x-\ldots)$ during controlled hyperglycaemia in seven insulin-treated diabetic patients. Results expressed as mean \pm SEM

tal haemoglobin (mean 7.9\%). Total $\mathrm{HbA}_{1 \mathrm{c}}$ increased significantly $2 \mathrm{~h}$ after induction of hyperglycaemia $(0.84 \pm 0.22 \%)$ and reached a stable level within 4-6 h. During the rest of the hyperglycaemic period no significant changes in $\mathrm{tA}_{\mathrm{lc}}$ were observed. The mean increase was $1.28 \pm 0.05 \%$ and range of observed increases $0.88 \%$ to $2.06 \%$ of total haemoglobin. After return of blood glucose to normal the $t \mathrm{~A}_{1 \mathrm{c}}$ concentration decreased to a level $0.17 \% \pm 0.04 \%$ higher than before hyperglycaemia $(2 p<0.05)$.

At 16 and $24 \mathrm{~h} \mathrm{iA} \mathrm{Ac}_{\mathrm{Ic}}$ was $0.09 \pm 0.05 \%$ and $0.13 \pm$ $0.07 \%$ higher than before hyperglycaemia. At $24 \mathrm{~h}$ this increase in $\mathrm{iA}_{\mathrm{lc}}$ was statistically significant in five of seven patients. Six hours after return of blood glucose to normal, $\mathrm{iA}_{\mathrm{lc}}$ was $0.10 \pm 0.04 \%$ higher than before hyperglycaemia. During hyperglycaemia, blood glucose concentrations were on average 22.2 $\pm 0.03 \mathrm{mmol} / 1$ and accordingly the average production of stable $\mathrm{HbA}_{1 \mathrm{c}}$ in $24 \mathrm{~h}$ was $0.006 \% / \mathrm{mmol}$ glucose. Results for $\mathbf{H b A}_{1 a+b}$ and thiobarbiturate reactive material are given in Table $1 ; \mathrm{iA}_{\mathrm{la}+\mathrm{b}}$ showed a significant increase $(2 p<0.05)$ in six of seven patients in response to hyperglycaemia, which was sustained after return of blood glucose to normal. In the thiobarbiturate assay, the relative increase in absorbance from before to after hyperglycaemia was close to that of $i A_{1 c}$.
Table 1. Stable $\mathrm{HbA}_{1 \mathrm{a}+\mathrm{b}}$, total $\mathrm{HbA}_{\mathrm{a}+\mathrm{b}}$ and thiobarbiturate reactive material in samples obtained before and after $24 \mathrm{~h}$ of hyperglycaemia, and $6 \mathrm{~h}$ after return of blood glucose to normal in seven insulin-treated diabetic patients

\begin{tabular}{llll}
\hline Component & $\begin{array}{l}\text { Before hyper- } \\
\text { glycaemia }\end{array}$ & $\begin{array}{l}\text { During hyper- } \\
\text { glycaemia }\end{array}$ & $\begin{array}{l}\text { After hyper- } \\
\text { glycaemia }\end{array}$ \\
\hline $\begin{array}{c}\text { Stable } \mathrm{HbA}_{\mathrm{la}+\mathrm{b}} \\
\% \text { of total } \\
\text { haemoglobin }\end{array}$ & $2.10 \pm 0.11$ & $2.30 \pm 0.11$ & $2.24 \pm 0.09$ \\
$\begin{array}{c}\text { Total HbA } \\
\text { \% of total } \\
\text { haemoglobin }\end{array}$ & $2.33 \pm 0.10$ & $2.54 \pm 0.12$ & $2.32 \pm 0.12$ \\
$\begin{array}{c}\text { Thiobarbiturate } \\
\text { absorbance }\end{array}$ & $0.173 \pm 0.009$ & & $0.176 \pm 0.011$ \\
\hline
\end{tabular}

Results expressed as mean \pm SEM

\section{Electrolytes and Metabolites}

Plasma sodium decreased significantly by $6 \mathrm{mmol} / 1$ $(2 p<0.05)$ during hyperglycaemia (range 130 $138 \mathrm{mmol} / \mathrm{l})$, but returned to normal after return of normoglycaemia (range $141-143 \mathrm{mmol} / \mathrm{l}$ ). No significant changes were noted in plasma potassium or bicarbonate (range 3.9-5.1 and $22.3-28.5 \mathrm{mmol} / 1$, respectively). During hyperglycaemia three patients had episodes of increased lipolysis and ketogenesis. The highest 3-hydroxybutyrate concentrations determined in these patients were $1.7,1.2$ and $0.6 \mathrm{mmol} / 1$, and in all three they returned to normal within a few hours after the infusion of supplementary insulin. Otherwise NEFA and 3-hydroxybutyrate values ranged from 70 to 960 and 40 to $560 \mu \mathrm{mol} / 1$, respectively.

\section{Density Separation}

Results for $\mathrm{iA}_{\mathrm{lc}}$ in density-separated erythrocytes and whole blood are shown in Table 2 . The concentration of $\mathrm{iA}_{1 \mathrm{c}}$ in unfractionated samples from out-patient insulin-dependent diabetics ranged from $6.4 \%$ to $10.3 \%$, in normal samples from $4.9 \%$ to $5.4 \%$ and in newly diagnosed diabetics from $10.1 \%$ to $17.5 \%$ before insulin treatment and from $8.6 \%$ to $12.3 \%$ after $31-35$ days of insulin treatment. The percentage of erythrocytes recovered in the 'low density' fraction ranged from $2.1 \%$ to $9.5 \%$ of the erythrocytes applied to the density mixture, and the reticulocyte fraction was four to ten times higher in the low density cells. The mean ratio of $\mathrm{HbA}_{1 \mathrm{a}+\mathrm{b}}$ or $\mathrm{HbA}_{\mathrm{lc}}$ concentration in the low density cells to that in whole blood did not differ significantly between normal subjects and diabetics. None had ratios above 1.0, and for $\mathrm{HbA}_{\mathrm{lc}}$ the lowest ratio determined was 0.66 and 0.69 in normal and diabetic samples respectively. Using the thiobarbiturate method 
Table 2. Stable glycosylated haemoglobins in low density erythrocytes and whole blood

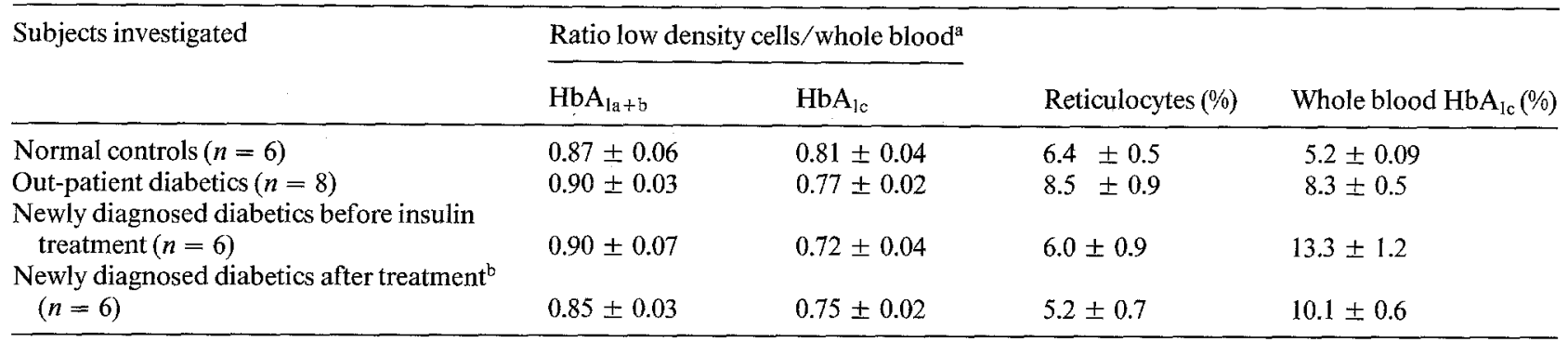

Results are expressed as mean \pm SEM

${ }^{\text {a }}$ on average $5.4 \%$ of the erythrocytes applied to the density gradient were recovered in the upper, less dense cell fraction (range $2.1 \%$ to $9.5 \%$ )

b same patients 31-35 days after start of insulin treatment

the ratio of absorbance in low density cells to that in whole blood was $0.90 \pm 0.02$ in six of the insulin dependent diabetic samples.

\section{Discussion}

Qualitatively, the changes in the unstable $\mathrm{HbA}_{1 \mathrm{c}}$ fraction observed during a $24 \mathrm{~h}$ period of induced hyperglycaemia in our diabetic patients closely resemble those previously reported from incubation of erythrocytes in glucose-containing media in vivo [5]. Thus, during a squarewave glucose profile in vivo, total $\mathrm{HbA}_{1 \mathrm{c}}$ reached a new stable level within $6 \mathrm{~h}$ of the increase in blood glucose concentration, and the increment nearly disappeared during the subsequent period of normoglycaemia.

Quantitatively, total $\mathrm{HbA}_{1 \mathrm{c}}$ increased by $0.058 \%$ of total $\mathrm{Hb} / \mathrm{mmol}$ glucose in vivo, and this is only slightly more than the $0.045 \% / \mathrm{mmol}$ glucose found after incubation of erythrocytes in vitro. From the correlation we previously reported between the unstable $\mathrm{HbA}_{\mathrm{lc}}$ fraction and the actual blood glucose concentration in out-patient diabetics [5], an increase of $1.08 \% \mathrm{tA}_{1 \mathrm{c}}$ was expected, and this is not significantly different from the $1.28 \%$ observed.

The average production of stable $\mathrm{HbA}_{\mathrm{lc}}, 0.006 \%$ / mmol glucose during a $24 \mathrm{~h}$ hyperglycaemic period, was comparable to the $0.009 \% / \mathrm{mmol}$ glucose calculated from the rate constant in vivo reported by Bunn et al. [6] using the model proposed by Beach [7], but lower than the $0.013 \% / \mathrm{mmol}$ glucose we previously found after incubation of erythrocytes in glucose $100 \mathrm{mmol} / 1$ saline. In contrast, the observed production of $\mathrm{HbA}_{1 \mathrm{c}}$ was an order of magnitude lower than that reported by Boden et al. [10] during the first week of deteriorated glucose control in insulin-independent patients. This difference persists even if the latter results are corrected for possible co-determination of $0.2 \%-0.4 \%$ unstable $\mathrm{HbA}_{1}$ formed during a
2-5 mmol/1 blood glucose increment. The reason for these differences is not known. Further, little is known at present about the influence of hormonal and metabolic factors on the glucose-haemoglobin interaction in vivo. In this study, the metabolic conditions - except for glucose - were fairly normal, and differences between erythrocyte and general metabolism may partly explain the reported differences in haemoglobin glycosylation in vivo, and the observed differences between synthesis in vitro and that in vivo found by us.

The results for density-separated erythrocytes show that both in normal and diabetic subjects whether controlled or newly diagnosed - the 5\% least dense cells contained $70 \%-80 \%$ of mean cell $\mathrm{HbA}_{1 \mathrm{c}}$, and the thiobarbiturate assay results confirmed the presence of a high fraction of ketoamine-bound glucose in the less dense cell fraction. Our mean ratios of $\mathrm{HbA}_{\mathrm{Ic}}$ in low density cells to whole blood $\mathrm{HbA}_{1 \mathrm{c}}$ are slightly higher than the $66 \%$ in normal subjects and $60 \%$ in diabetics calculated from the data reported by Fitzgibbons et al. [9], who separated the 10\% least dense cells. However, all our subjects have ratios within the ranges calculated from data of Fitzgibbon et al. In close agreement with our data, Labie [8] recently reported the major proportion of $\mathrm{HbA}_{1 \mathrm{c}}$ to be present in the 5\% least dense cells. Labie also reported absence of glycosylated haemoglobins in erythroblasts from the bone marrow, whereas Beach [7] from model studies postulated that $\mathrm{HbA}_{1 \mathrm{c}}$ might be present in new erythrocytes entering the circulation.

The validity of density separation as a method for age separation of erythrocytes has been based mainly upon differences in enzyme, haemoglobin and electrolyte concentrations in the density-separated cells [15]. Recently Luthra et al. [16], using ${ }^{59} \mathrm{Fe}$-labelling of haemoglobin in vivo, showed that although young erythrocytes tended to concentrate in the least dense cell fractions, a substantial fraction of the young erythrocytes rapidly achieved differert densities and 
consequently distributed nearly uniformly throughout a density gradient.

If the proposed slow, nearly linear increase in $\mathrm{HbA}_{\mathrm{Ic}}$ during erythrocyte life span is correct, two major discrepancies in our results for $\mathrm{HbA}_{1 \mathrm{c}}$ in densityseparated erythrocytes need to be resolved. First, if density separation resulted in age separation the 5\% least dense and youngest cells should contain less than $10 \%$ of mean cell or whole blood $\mathrm{HbA}_{1 \mathrm{c}}$, whereas $70 \%-80 \%$ was found in all groups investigated. Secondly, the ratio of $\mathrm{HbA}_{\mathrm{Ic}}$ in young cells to whole blood was expected to decrease to less than one half after a 30 day period of improved control in the group of newly diagnosed diabetics. No decrease in the ratio was found although whole blood $\mathrm{HbA}_{\mathrm{Ic}}$ showed a substantial decrease. The second discrepancy, unlike the first, cannot be explained by postulating either that the hyperglycaemic period before improved control lasted less than the usual 120 day erythrocyte life span, or alternatively that there was some dissociation of circulating $\mathrm{HbA}_{1 \mathrm{c}}$.

Most clinical studies have reported a significant correlation between glycosylated haemoglobins and measures of glucose control. This proves glucose to be a major determinant, but not necessarily the only one, for the formation of $\mathrm{HbA}_{1 \mathrm{c}}$. Thus, it has recently been reported that iron deficiency [17] and nephropathy [18] per se increased the $\mathrm{HbA}_{1 \mathrm{c}}$ concentration, and other factors influencing synthesis and stability of $\mathrm{HbA}_{1 \mathrm{c}}$ may come to light.

A low rate of $\mathrm{HbA}_{1 \mathrm{c}}$ synthesis has been described in this and other studies for normal subjects and diabetics having a fairly constant blood glucose concentration, but prediction of $\mathrm{HbA}_{\mathrm{lc}}$ concentrations in diabetics showing widely varying glucose values from such data may be difficult. In this context it is still uncertain whether identical mean blood glucose concentrations with different amplitudes of excursions around the mean will provide identical concentrations of glycosylated haemoglobins.

There is clearly a need for further studies on the rate of formation of aldimine $\mathrm{HbA}_{1 \mathrm{c}}$ and its conversion to ketoamine $\mathrm{HbA}_{1 \mathrm{c}}$ and on factors influencing this process, before complete understanding of the relationship between $\mathrm{HbA}_{\mathrm{lc}}$ and glucose control in diabetics can be achieved.

\section{References}

1. Flock EV, Bennet PH, Savage PJ, Webner CJ, Howard BV, Rushforth NB, Moller M (1979) Bimodality of glycosylated haemoglobin distribution in Pima Indians. Diabetes: 28: 984-989
2. Paisey RB, McFarlane DG, Sheriff RJ, Hartog M, Slade RR, White DAJ (1980) The relationship between blood glycosylated haemoglobin and home capillary blood glucose levels in diabetics. Diabetologia 19:31-34

3. Svendsen PAa, Christiansen JS, Welinder BS, Nerup J (1979) Fast glycosylation of haemoglobin. Letter to the editor. Lancet 1: 603

4. Widness JA, Rogler-Brown TL, McCormick KL, Petzold KS, Susa JB, Schwartz HC, Schwartz R (1980) Rapid fluctuations in glycohemoglobin (hemoglobin $A_{1 c}$ ) related to acute changes in glucose. J Lab Clin Med 95:386-395

5. Svendsen PAa, Christiansen JS, Søegaard U, Welinder BS, Nerup J (1980) Rapid changes in chromatographically determined haemoglobin $A_{1 c}$ induced by short-term changes in glucose concentration. Diabetologia 19:130-136

6. Bunn HF, Haney DN, Kamin S, Gabbay KH, Gallop PM (1976) The biosynthesis of human haemoglobin $A_{1 c}$ J Clin Invest $57: 1652-1659$

7. Beach KW(1979) A theoretical model to predict the behavior of glycosylated hemoglobin levels. J Theor Biol 81:547-561

8. Labie D, Wajcmann H, Krishnamoorthy R, Cahour A, Hartmann L (1979) Glycosylation non-enzymatique de l'hemoglobine chez le sujet normal et diabétique. CR Soc Biol 173: $321-330$

9. Fitzgibbons JF, Koler RD, Jones RT (1976) Red cell age-related changes of hemoglobins $A_{\mathrm{la}+\mathrm{b}}$ and $\mathrm{A}_{\mathrm{lc}}$ in normal and diabetic subjects. J Clin Invest 58: 820-824

10. Boden G, Master RW, Gordon SS, Shumann CR, Owen OE (1980) Monitoring metabolic control in diabetic outpatients with glycosylated hemoglobin. Ann Intern Med 92: 357-360

11. Pecorado RE, Graff RJ, Halter JB, Beiter H, Porte D (1979) Comparison of a colorimetric assay for glycosylated hemoglobin with ion-exchange chromatography. Diabetes 28: $1120-1125$

12. Trinder $P$ (1969) Determination of glucose in blood using an alternative oxygen receptor. Ann Clin Biochem 6:24-27

13. Duncomb WG (1964) A colorimetric method for the determination of FFA. Clin Chim Acta 9: 122-125

14. Wildenhoff KE (1970) A micromethod for determination of acetoacetate and $\beta$-hydroxybutyrate in blood and urine. Scand J Clin Lab Invest 25: 171-179

15. Rennie CM, Thompson S, Parker AC, Maddy A (1979) Human erythrocyte fractionation in "Percoll" density gradients. Clin Chim Acta 98: 119-125

16. Luthra MG, Friedman JM, Sears DA (1979) Studies of density fractions of normal human erythrocytes labeled with iron-59 in vivo. J Lab Clin Med 94: 879-896

17. Brooks AP, Metcalfe J, Day JL, Edwards MS (1980) Iron deficiency and glycosylated haemoglobin $\mathrm{A}_{1}$. Letter to the editor. Lancet 2: 141-142

18. de Boer M-J, Miedema K, Casparie AF (1980) Glycosylated haemoglobin in renal failure. Diabetologia 18: $437-440$

Received: 20 October 1980

and in revised form: 20 July 1981

P. Aaby Svendsen

Clinical Chemistry Department

Steno Memorial Hospital

DK-2820 Gentofte, Denmark 